Article

\title{
Effect of Brazing Temperature on the Microstructure and Chosen Properties of WC-10Ni/NiCrBSi Composite Coatings Produced by Vacuum Cladding from Flexible Coated Cloths
}

\author{
Xiangping Xu, Hengnan Ding, Chunzhi Xia, Jiasheng Zou * and Yi Wang \\ School of Materials Science and Engineering, Jiangsu University of Science and Techology, \\ Zhenjiang 212003, China; 201100003039@just.edu.cn (X.X.); 62060010@stu.just.edu.cn (H.D.); \\ czxia@just.edu.cn (C.X.); 172060051@stu.just.edu.cn (Y.W.) \\ * Correspondence: 198600000504@just.edu.cn; Tel.: +86-0511-8440-1182
}

Received: 5 March 2019; Accepted: 25 March 2019; Published: 27 March 2019

check for updates

\begin{abstract}
Three kinds of $\mathrm{WC}-10 \mathrm{Ni} / \mathrm{NiCrBSi}$ composite coatings were prepared on the surface of Q235 carbon steel at 1015,1055 , and $1095^{\circ} \mathrm{C}$ by vacuum brazing. The microstructure and properties of the composite coatings were investigated. The results showed that various reaction layers appeared at the bonding area of the coatings and the substrate. As the brazing temperature increased, the reaction layer between the solder and the hard phase gradually decreased and disappeared at $1095{ }^{\circ} \mathrm{C}$. Simultaneously, the size of gray-white massive phases with a large amount of $\mathrm{W}$ in the brazing layer decreased gradually. When the brazing temperature increased, the Fe content markedly increased in the reaction layer of the matrix and the solder, indicating that the increase in brazing temperature was beneficial for metallurgical bonding between the coating and the substrate. Interface bonding strength and wear resistance were enhanced by the increase in brazing temperature; however, the microhardness of the composite coating section decreased. The interface bonding strength reached $362.9 \mathrm{MPa}$ and the wear loss reached a minimum at $1095{ }^{\circ} \mathrm{C}$.
\end{abstract}

Keywords: vacuum brazing; WC-10Ni; Micromorphology; composite coating

\section{Introduction}

The excellent surface properties of materials are of interest to many industries, including the aerospace and oil industries [1]. However, common surface methods for metal materials have their own disadvantages. For instance, thermal spray coatings and base metal bonds are mainly mechanically fitted, so their impact resistance is not great. Owing to uneven heating in the welding process, the temperature gradient in the surfacing welding process is large, leading to high welding stress, deformation, and even cracking. The strengthening thickness of gas-phase deposition coatings is relatively thin [2-12].

The flexible "coated cloth" technology originated in the 1960s and 1970s and was invented by Goldsmith and Breton $[13,14]$. The main process involved in the flexible "coated cloth" technology is mixing of the powdery hard particles, the bonding metal, and the organic binder with a stirring device. The hard particle powder and the binder metal powder are then wrapped in an organic binder by other molding processes, thereby producing a material with good flexibility. Lu prepared an $\mathrm{NiCrBSi} / \mathrm{WC}-\mathrm{Co}$ wear-resistant composite coating by combining vacuum brazing technology with flexible "coated cloth" technology. By analyzing the microstructure of this "coated cloth", he believed that the organic binder formed a staggered spider web structure under the repeated extrusion of the rolls, and the granular powder was embedded in it [15]. Tan studied the effect of brazing 
processes on the properties of the WC "coated cloth" layer, finding that the wear resistance of the coating increased with an increase in brazing temperature, but the resistance decreased when the brazing temperature exceeded $1080^{\circ} \mathrm{C}$ [16]. In general, coatings prepared by a combination of vacuum cladding and flexible "coated cloth" technology have a characteristic low internal stress, controllable thickness, higher surface hardness, and better wear resistance. At the same time, flexible metal cloth can overcome the problems of complicated structures and the location of the workpiece [17-19].

In this paper, based on the research status and development trend of cemented carbide coatings at home and abroad [20], WC-NiCrBSi composite coatings were prepared on the surface of substrate Q235 by combining vacuum brazing technology and flexible "coated cloth" technology. The effect of changing the brazing temperature on the coating was studied by examining the microstructure and properties of coatings after vacuum cladding, to understand the engineering applications of this type of coating.

\section{Materials and Methods}

\subsection{Materials and Coating Preparation Process}

The base material was Q235 carbon steel $(70 \mathrm{~mm} \times 30 \mathrm{~mm} \times 5 \mathrm{~mm})$ and its mechanical characteristics are shown in Table 1. Nickel-coated tungsten carbide WC-10Ni powders were used as the hard phase in the composite coating, in two sizes of 30-45 $\mu \mathrm{m}$ and $5-15 \mu \mathrm{m}$. The WC-10Ni powders were prepared by sintering agglomerates of WC particles and Ni. NiCrBSi powders of type BNi-2 (Table 2) were selected as solder and their solidus and liquidus temperatures were 917 and $999^{\circ} \mathrm{C}$, respectively, and the powder diameter was less than $45 \mu \mathrm{m}$. The microscopic morphology of WC-10Ni powder and WC BNi-2 powder is shown in Figure 1. PTFE powder was used as the binder phase in the "metal cloth" rolling process.

Preparation of the "coated cloths" was divided into three steps: the first step was to mix the three different powders with a QM-5 roller mill for $5 \mathrm{~h}$ according to the proportion shown in Table 3; the second step was to roll the mixed powders repeatedly into a $1 \mathrm{~mm}$ thick "Carbide cloth" and "Solder cloth", which are shown in Figure 2; and the third step was to cut the cloths to the size of $70 \mathrm{~mm} \times$ $30 \mathrm{~mm}$.

In this test, a WZB-20 vacuum brazing furnace (Zhongshan, China) was adopted. Before brazing, the surface of the Q235 steel was ground with water-abrasive papers and then ultrasonically cleaned in an acetone solution and dried. The sample assembly method is shown in Figure 3. Three vacuum brazing temperatures were used in the test for comparison, which were 1015,1055 , and $1095{ }^{\circ} \mathrm{C}$. The vacuum degree during brazing was not less than $2 \times 10^{-3} \mathrm{~Pa}$, and the brazing process curve is shown in Figure 4. Three metallographic samples of $15 \mathrm{~mm} \times 5 \mathrm{~mm}$ were removed from each sample after brazing.

Table 1. Mechanical characteristics of Q235 carbon steel.

\begin{tabular}{cccccc}
\hline Material & $\begin{array}{c}\text { Density } \\
\left(\mathbf{c m}^{\mathbf{3}}\right)\end{array}$ & $\begin{array}{c}\text { Elastic Modulus } \\
\mathbf{( G P a )}\end{array}$ & $\begin{array}{c}\text { Poisson's } \\
\text { Ratio }\end{array}$ & $\begin{array}{c}\text { Tensile Strength } \\
\mathbf{( M P a}\end{array}$ & $\begin{array}{c}\text { Yield Strength } \\
\mathbf{( M P a})\end{array}$ \\
\hline Q235 & 7.85 & $200-210$ & $0.25-0.33$ & $370-500$ & 235 \\
\hline
\end{tabular}

Table 2. Chemical composition of BNi-2 (wt.\%).

\begin{tabular}{cccccccc}
\hline Chemical Composition & $\mathbf{C r}$ & $\mathbf{B}$ & $\mathbf{S i}$ & $\mathbf{C}$ & $\mathbf{F e}$ & $\mathbf{P}$ & $\mathbf{N i}$ \\
\hline Mass fraction & $6.0-8.0$ & $2.75-3.5$ & $4.0-5.0$ & 0.06 & $2.5-3.5$ & 0.02 & $79.92-84.67$ \\
\hline
\end{tabular}



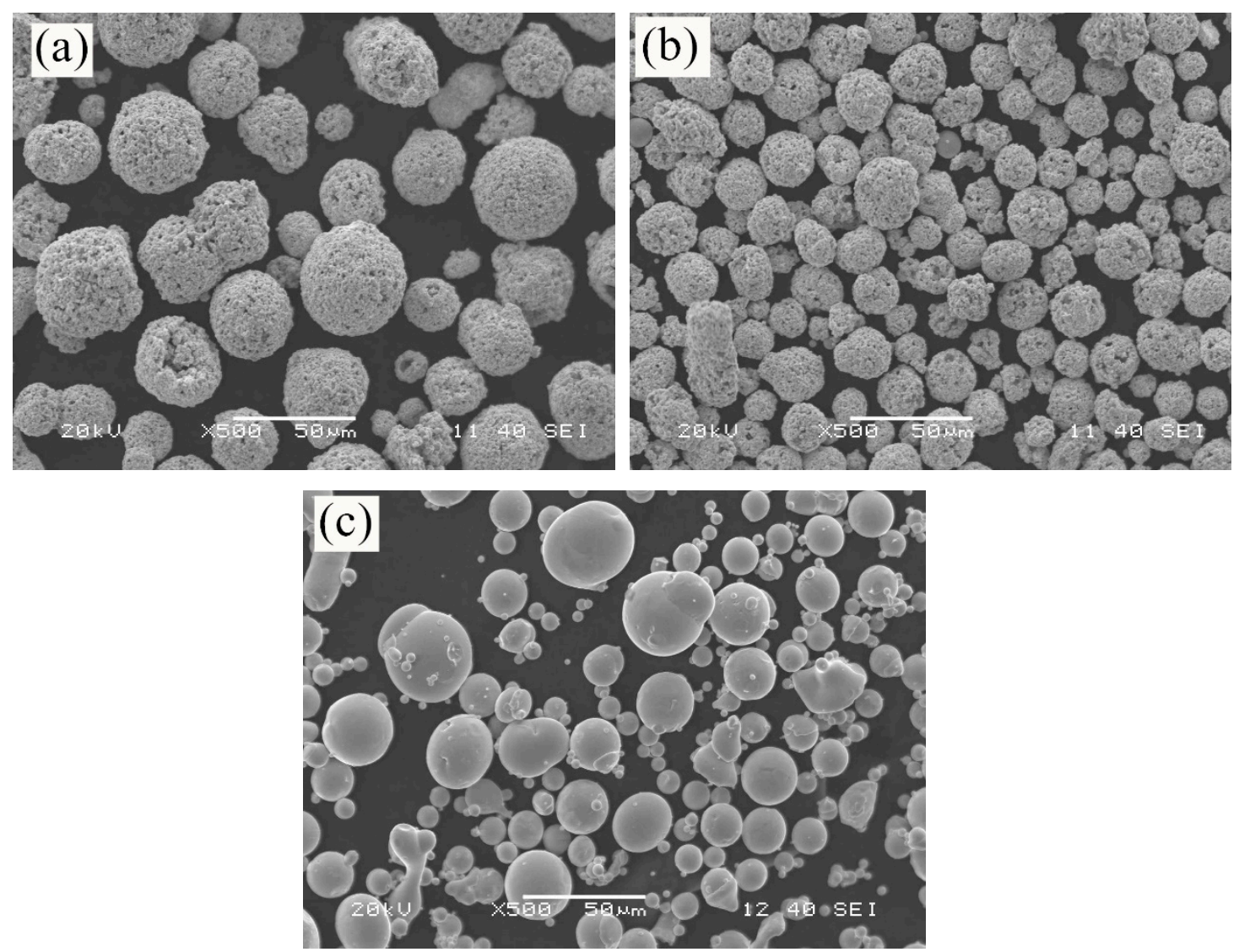

Figure 1. Microscopic morphology of various powders: (a) 30-45 $\mu \mathrm{m}$ WC-10Ni, (b) $5-15 \mu \mathrm{m} \mathrm{WC}-10 \mathrm{Ni}$, and (c) BNi2.

Table 3. Proportion of components in the metal cloth.

\begin{tabular}{ccccc}
\hline Metal Cloth Type & WC-10Ni (5-15 $\boldsymbol{\mu m})$ & WC-10Ni (30-45 $\boldsymbol{\mu m})$ & NiCrBSi & PTFE \\
\hline carbide cloth & 3 & 3 & 4 & 0.16 \\
solder cloth & - & - & 10 & 0.16 \\
\hline
\end{tabular}

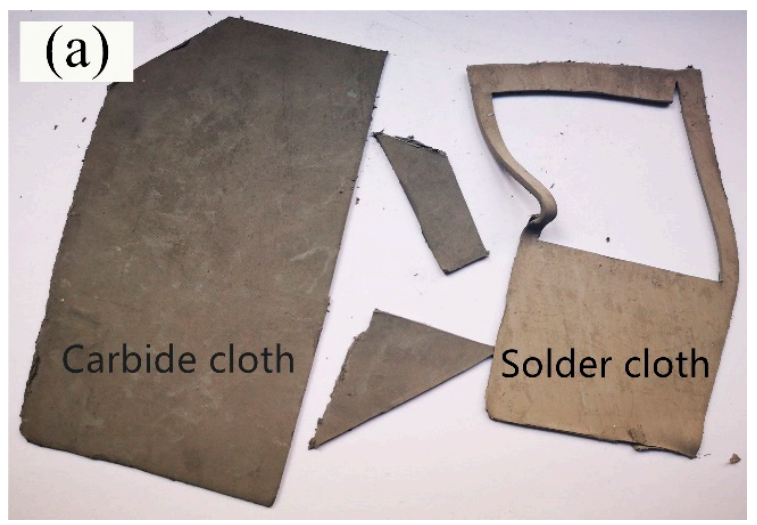

Figure 2. Cont. 

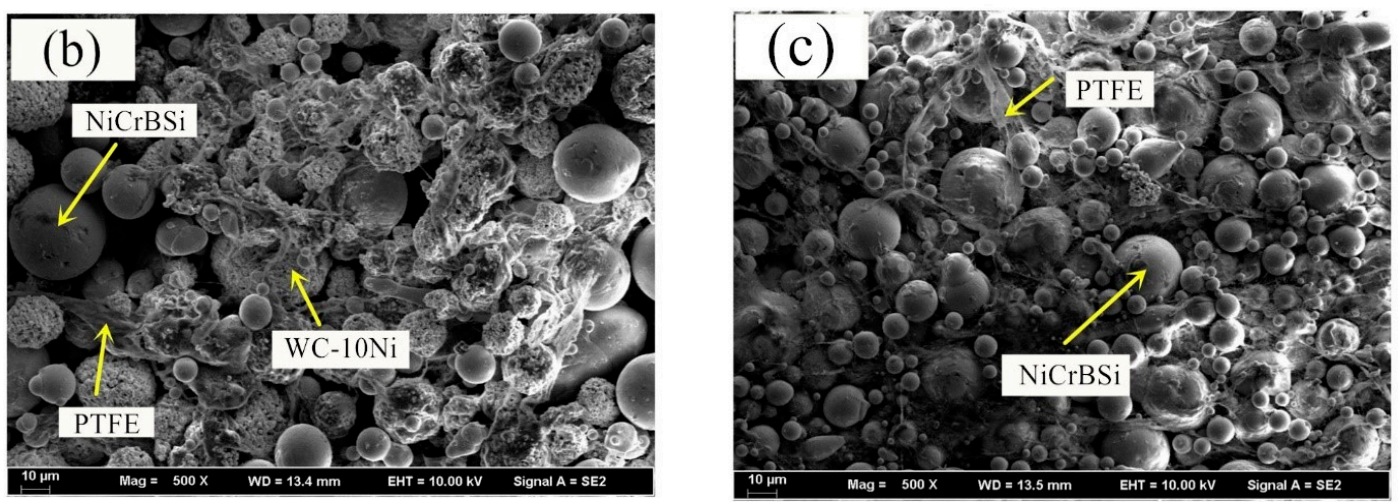

Figure 2. (a) Macro appearance of metal cloth; (b) microscopic morphology of "Solder cloth"; (c) microscopic morphology of "Carbide cloth".

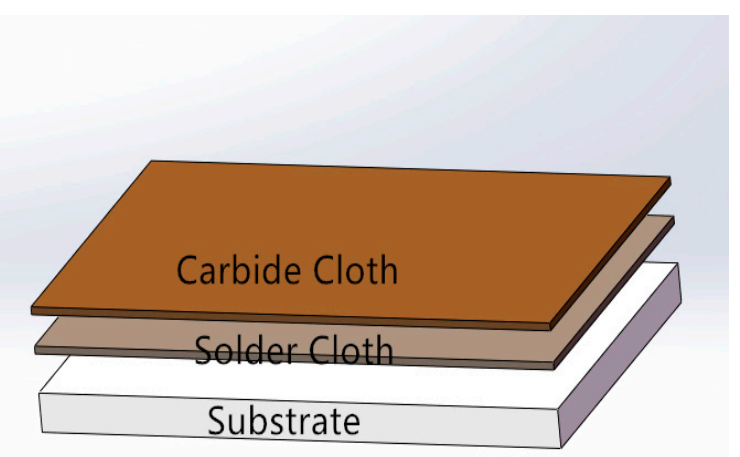

Figure 3. Sample assembly method.

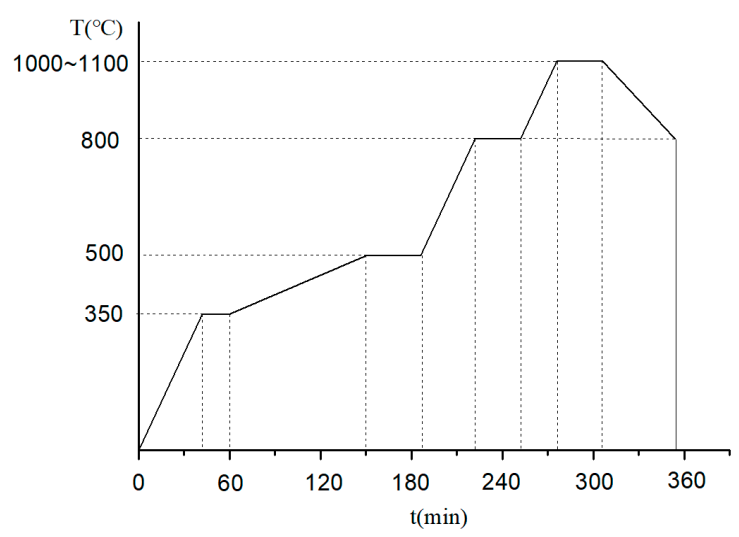

Figure 4. Welding process curve.

\subsection{Micromorphology Characterizations}

The cross-sectional morphology of the coating was observed by means of a Zeiss Axioskop2 metallographic microscope (Oberkochen, Germany). Punctual and linear elemental analyses were performed on the characteristic areas of the coating cross-section with a JSM-6480 scanning electron microscope with an energy spectrum analyzer (Kyoto, Japan). The side face of the sample was analyzed by an XRD-6000 X-ray diffractometer (Tokyo, Japan) with $\mathrm{Cu} \mathrm{K} \alpha$ radiation $(\lambda=1.54 \AA)$. 


\subsection{Hardness and Shear Test}

The bonding strength of the coating interface was tested with a CMT5205 electronic universal testing machine (Zhuhai, China) and a self-designed cutting fixture. The test schematic is shown in Figure 5a. The size of the shear sample is $4 \mathrm{~mm} \times 10 \mathrm{~mm} \times 7 \mathrm{~mm}$ and each coating was tested five times. The microhardness of different depths of the coating section was tested with a KB 30S FA BASIC automatic hardness tester (Hochdorf-Assenheim, Germany), the test load was $200 \mathrm{gf}$, and the load time was $20 \mathrm{~s}$. The test schematic for this is shown in Figure $5 \mathrm{~b}$.

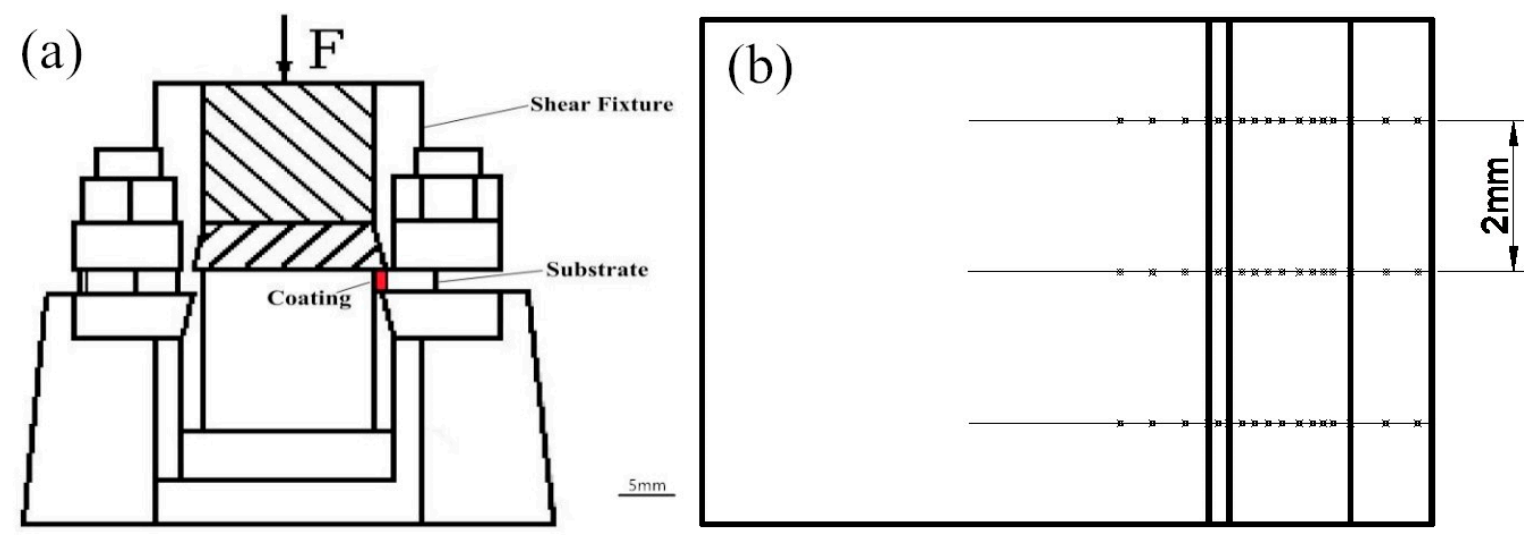

Figure 5. (a) Shear test schematic; (b) microhardness test diagram.

\subsection{Wear Resistance Test}

In order to quantify the wear resistance of coatings, $1 \mathrm{~mm}$ of the coating surface was removed and a HT-1000 high temperature friction and wear tester (Lanzhou, China) was used. The specific test parameters were as follows: the test temperature was room temperature; the friction pair was a $\mathrm{Si}_{3} \mathrm{~N}_{4}$ ceramic ball of $5 \mathrm{~mm}$ in diameter; the load applied in the test was $20 \mathrm{~N}$; the rotational speed of the grinding disc was $600 \mathrm{r} / \mathrm{min}$; the wear radius was $4 \mathrm{~mm}$; and the wear time was $1 \mathrm{~h}$. In order to obtain accurate data, each coating was tested five times.

\section{Results}

\subsection{Microstructure}

Figure 6 a shows the microstructure of the coating with a soldering temperature of $1055{ }^{\circ} \mathrm{C}$. In the process of brazing, the NiCrBSi solder liquefied, while the WC particles did not decompose. Due to the density of WC being higher than that of the NiCrBSi and the gravity of WC, the WC settled downward and accumulated in areas near the brazing layer. As the brazing temperature increased, the fluidity of the solder increased, and thus the WC particles could sink further into the liquid solder, leading to the increasing amount of liquid solder without WC particles above the coating. As can be seen in Figure $6 b$, these liquid solders flowed to the back of the sample due to the lack of support from the WC particles. 

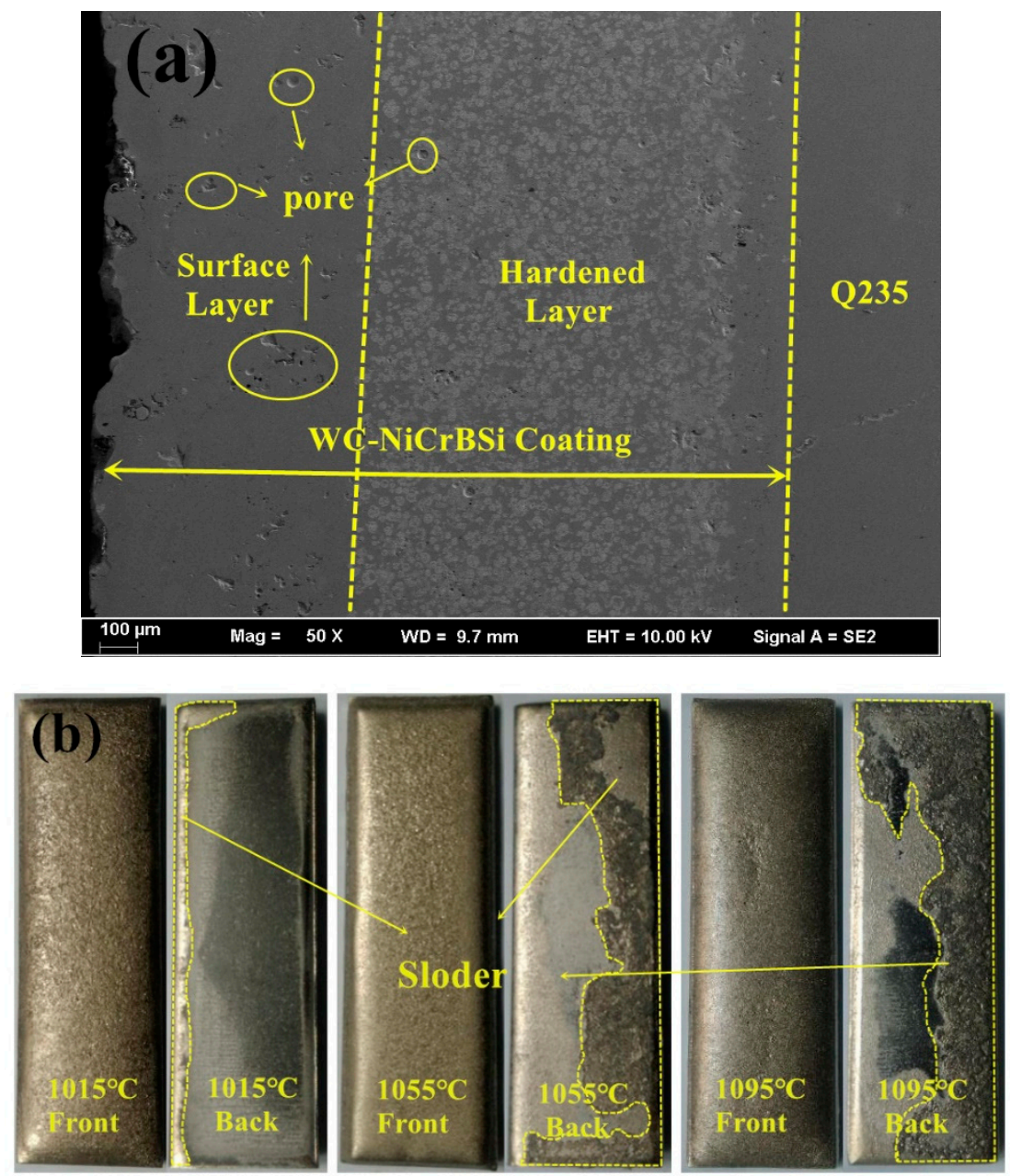

Figure 6. (a) Micromorphology of the coating with a soldering temperature of $1055^{\circ} \mathrm{C}$; (b) The front and back morphology of samples.

\subsection{Interface Morphology and Element Distribution}

The microstructures of the bonding area of the coatings and substrate brazed at 1015, 1055, and $1095{ }^{\circ} \mathrm{C}$ are shown in Figure 7. The circular vesicular structure in Figure 7 is the WC particles, and the area around the WC particles is filled with an Ni-based solid solution and compound. As can be seen from Figure 7, this study divided the section into four different reaction layers: Layer I was the "hard layer" composed of gray Ni-based solid solutions and bright white vesicular WC particles; layer II was the reaction layer of the hard phase and the solder, composed of Ni-based solid solutions, WC particles, and gray-white massive phases; layer III was the reaction layer of the matrix and the solder, composed of Ni-based solid solutions and gray-white massive phases, with almost no WC particles; and layer IV was the Q235 matrix. Comparing Figure 7a-c, it was found that layer II became narrower with the increase in brazing temperature, disappearing at $1095^{\circ} \mathrm{C}$.

As the brazing temperature increased, the fluidity of the liquid solder also increased. The pores generated by the high-temperature volatilization of the binder added during the "solder cloth" preparation process allowed for better overflow, and the size as well as the number of pores in layer III gradually decreased. Obviously, the increase of brazing temperature caused the size of the gray-white massive phases to become smaller. 

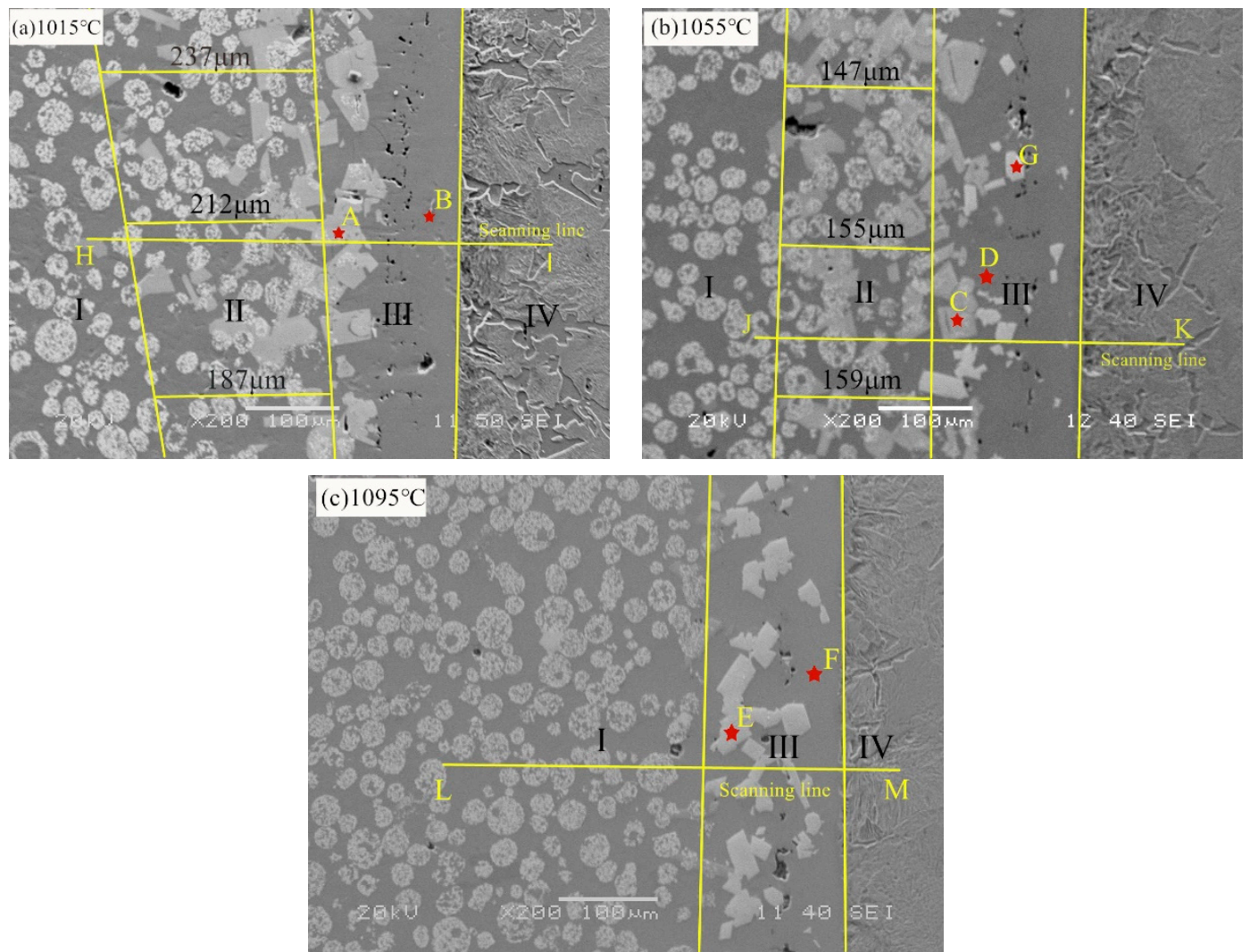

Figure 7. Microstructures of the bonding area of the coatings and substrate brazed at different temperatures: (a) $1015^{\circ} \mathrm{C}$, (b) $1055^{\circ} \mathrm{C}$, and (c) $1095^{\circ} \mathrm{C}$.

In order to further study the influence of different brazing temperatures on the interface structure of the coating, seven characteristic regions were analyzed by EDS. The characteristic regions B, D, and $\mathrm{F}$ were located at Ni-based solid solutions in layer III on the samples prepared at different brazing temperatures, and A, C, E, and G were located at the gray-white massive phases in layer III on these samples. As can be seen in Table 4, the characteristic regions B, D, and F were mainly composed of $\mathrm{Ni}$ and a little of $\mathrm{Fe}, \mathrm{Si}$, and $\mathrm{Cr}$. According to the phase diagram of the $\mathrm{Ni}-\mathrm{Cr}$ and $\mathrm{Fe}-\mathrm{Ni}$ binary alloys, the regions were composed of $\gamma-\mathrm{Ni}(\mathrm{Fe}, \mathrm{Cr})$ and $\alpha-\mathrm{Ni}(\mathrm{Si})$ solid solution phase. Comparing the characteristic regions $\mathrm{B}, \mathrm{D}$, and $\mathrm{F}$, it was found that as the brazing temperature increased, the Fe content increased significantly.

Table 4. Composition of points marked in Figure 8.

\begin{tabular}{cccccc}
\hline \multirow{2}{*}{ Representative Points } & \multicolumn{5}{c}{ Elemental Composition(wt.\%) } \\
\cline { 2 - 6 } & Si & Cr & Fe & Ni & W \\
\hline A & 5.0 & 22.8 & 1.4 & 27.8 & 43.1 \\
C & 5.1 & 21.2 & 0.7 & 25.6 & 47.4 \\
E & 7.9 & 11.1 & 1.7 & 15.5 & 63.8 \\
G & 9.0 & 7.1 & 2.1 & 13.4 & 68.5 \\
B & 9.2 & 7.3 & 7.1 & 76.3 & - \\
D & 8.8 & 5.6 & 16.3 & 69.4 & - \\
F & 8.6 & 5.5 & 19.6 & 66.3 & - \\
\hline
\end{tabular}


The WC particles used in the test were WC-10Ni, and the $10 \% \mathrm{Ni}$ added in the hard layer diluted the melting elements $\mathrm{Si}$ and B in the solder. Simultaneously, the presence of WC-10Ni in the "Carbide cloth" compared to the "Solder cloth" resulted in a difference in elemental density between them. In the vacuum brazing process, due to the high content of the melting element in the "solder cloth", a large amount of Si and B diffused from the interface between the "carbide cloth" and "solder cloth" into the hard layer in order to achieve the balance of the element concentration in the coating, and the side of the interface near the "carbide cloth" became the "output end" of Si and B, resulting in a significant decrease in the melting point of the side. The melting point of $\mathrm{WC}$ is $2870{ }^{\circ} \mathrm{C}$, so the separate WC particles did not undergo any transformation under vacuum conditions of $1100^{\circ} \mathrm{C}$, but they may form a dissolution after mixing with the metal matrix [21,22]. The affinity of $\mathrm{Cr}$ to $\mathrm{C}$ was higher than that of $\mathrm{W}$ and $\mathrm{C}$, and $\mathrm{W}$ in $\mathrm{WC}$ could be preferentially replaced. Therefore, $\mathrm{Cr}$ in $\mathrm{NiCrBSi}$ was also a cause of dissolution of WC and this dissolution led to the generation of the gray-white massive phase. The characteristic areas A, C, E, and G (gray-white massive phases) were composed of a large number of $\mathrm{W}$, some $\mathrm{Cr}$ and $\mathrm{Ni}$, and a small amount of $\mathrm{Si}$ and $\mathrm{Fe}$. A large amount of $\mathrm{W}$ content caused the hardness of these phases to be high, leading to a decrease in the bond strength at the bonding surface of the substrate coating. With the increase in brazing temperature, the content of $\mathrm{Cr}$ in gray-white massive phases decreased, the content of $\mathrm{W}$ increased greatly, and its size decreased gradually, which improved the toughness between the Q235 substrate and coating.

The line scan of the elements at HI, JK, and LM in Figure 7 was performed by EDS, and the results are shown in Figure 8a-c. Cr was mainly distributed in the gray-white massive phases formed after WC dissolution. With the increase in brazing temperature, the content of the gray-white phases decreased, and the distribution of $\mathrm{Cr}$ became relatively uniform. It is notable that $\mathrm{Si}$ has the same distribution tend as W. This is because the $\mathrm{Si}$ in the NiCrBSi was diffusing into and accumulating in the WC particles when it was melted. Subsequently, in the process of heat preservation, due to the crystallization of the isothermal solidification, part of the $\gamma$-Ni solution without $\mathrm{Si}$ formed and the remaining liquid with $\mathrm{Si}$ non-isothermally curdled. During the brazing process, the Fe in the matrix dissolved and diffused, forming a metallurgical belt with the interface, which formed a strong metallurgical bond between the coating and the matrix. However, due to the large atomic radius of $\mathrm{Fe}$, the diffusion distance was limited, thus the Fe was distributed like a cliff after undergoing the metallurgical bond. The increase in brazing temperature increased the diffusion coefficient of the element, causing more Fe to dissolve and diffuse, and it was found from Figure 8 that the Fe content in layer III markedly increased when the brazing temperature increased. Therefore, the increase in brazing temperature was beneficial for the metallurgical bonding between the coating and the substrate.
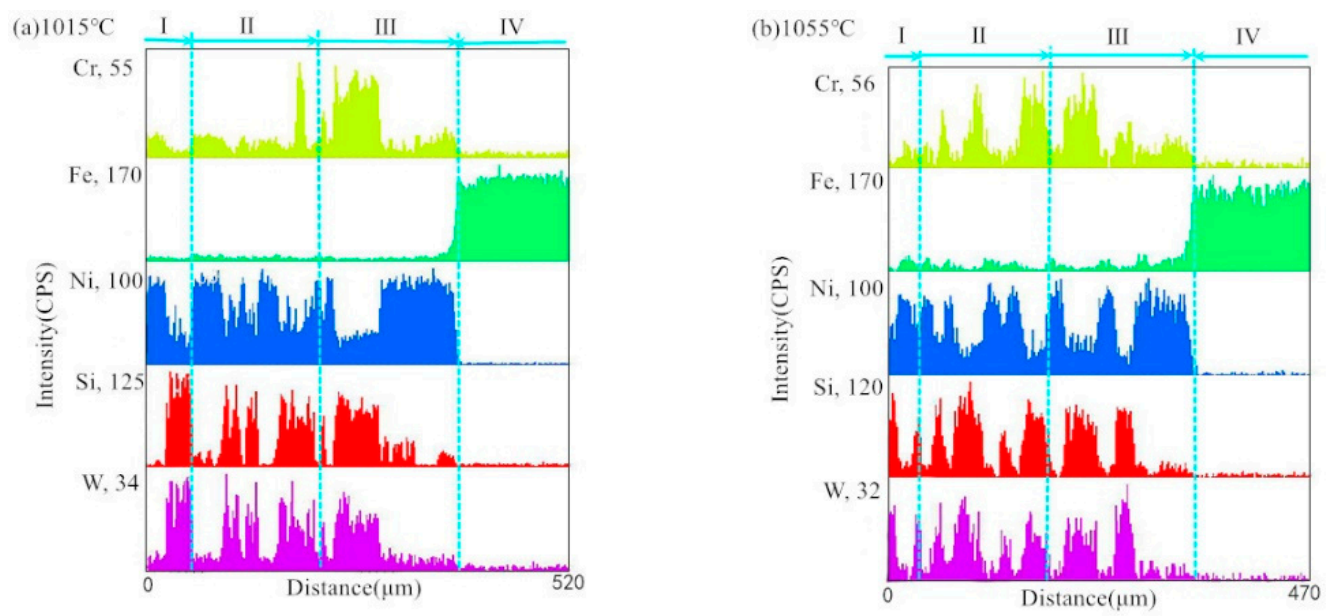

Figure 8. Cont. 


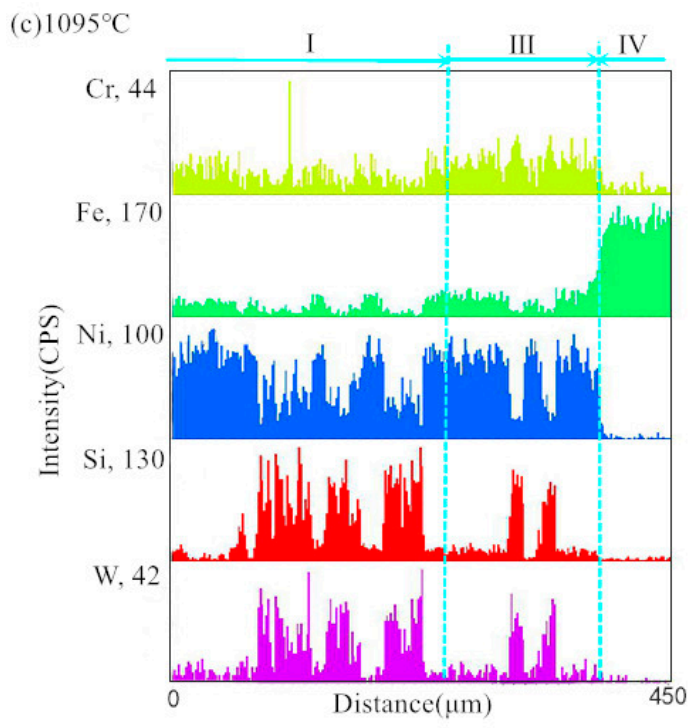

Figure 8. Element distribution at the brazed interface: (a) $1015^{\circ} \mathrm{C}$; (b) $1055^{\circ} \mathrm{C}$; and (c) $1095{ }^{\circ} \mathrm{C}$.

\subsection{Phase Composition of Composite Coating}

The cross-section of the sample which contains the surface layer, hardened layer, and Q235 substrate layer with a brazing temperature of $1055^{\circ} \mathrm{C}$ was analyzed by $\mathrm{X}$-ray diffraction. As shown in Figure 9, the composite coating contained WC, $\alpha$-Fe, and $\gamma$-Ni solid solution, and a small amount of $\mathrm{Ni}_{3} \mathrm{Si}$ phase. The $\gamma$-Ni solid solution played a supporting role to WC in the coating, and the $\mathrm{Ni}_{3} \mathrm{Si}$ phase that was dispersed in the coating dispersion strengthened the coating.

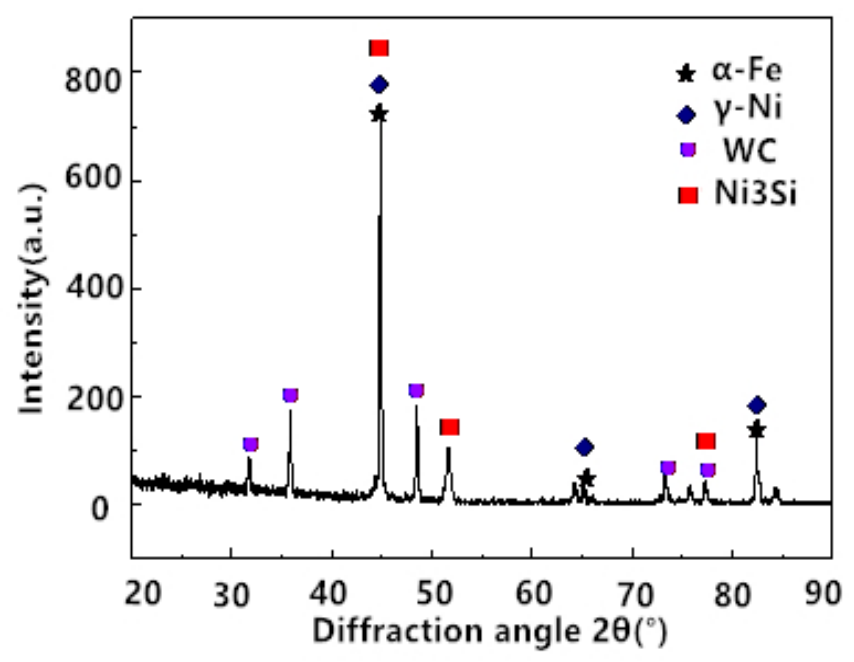

Figure 9. Cross-sectional XRD of the $1055^{\circ} \mathrm{C}$ composite coating.

\subsection{Microhardness of Composite Coating Sections}

The microhardness value curves of the three different brazing temperature coating sections at different depths are shown in Figure 10. The microhardness of the composite coatings section showed the shape of a peak that first increased then decreased from the substrate to the surface layer. By comparison, the microhardness of the hardened layer was higher than that of the substrate, which is about six to seven times that of the substrate. Due to the non-uniformity of WC particle distribution in the hard layer, in the microhardness test, the hardness tester head might have been on the WC particles, causing the microhardness value to fluctuate. At the interface, there was mainly a nickel-based solid solution with some iron elements in the substrate dissolved in it, which was a soft single crystal 
structure with low hardness that played a good transition between the hard layer and substrate and improved the bonding strength of the coating interface. It can be seen from Figure 10 that as the brazing temperature increased, the microhardness of the interface decreased. This was due to the following: the rise in temperature which increased the diffusion coefficient of the alloying elements $\mathrm{Si}$ and B; the increased amount of Fe that dissolved and diffused towards the interface in the matrix; and the brittleness at the interface that was reduced, thereby reducing the hardness.

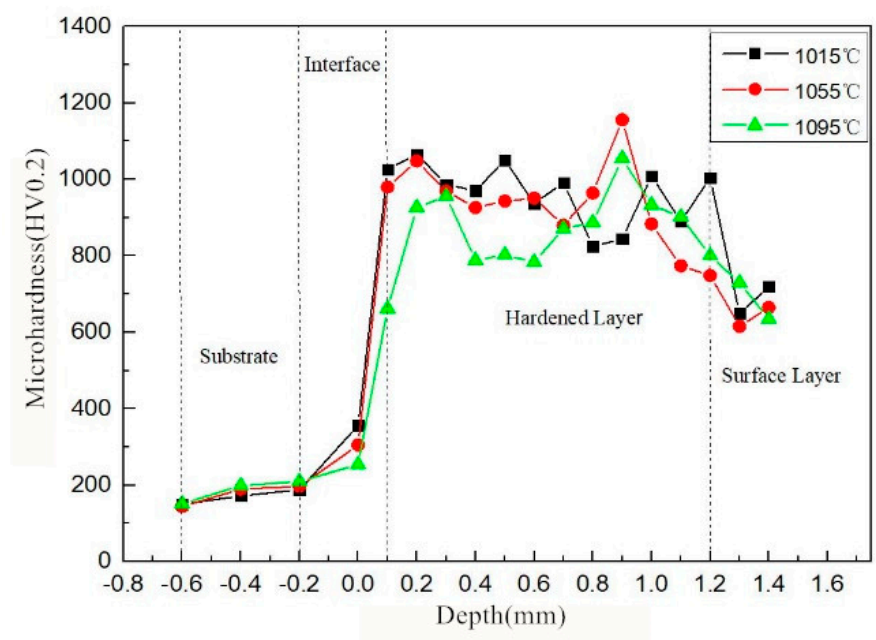

Figure 10. Microhardness of the composite coatings section.

\subsection{Bonding Strength between the Coating and Substrate}

In order to study the bonding strength between the WC-NiCrBSi coating and matrix at different brazing temperatures, the specimen was subjected to a shear test. The results are shown in Figure 11. The interfacial shear strength values of the three coatings were 270.2, 336.7, and $362.9 \mathrm{MPa}$. The results indicated that metallurgical bonding was formed between the coating and the matrix. The increase in brazing temperature improved the fluidity of the liquid solder and its wettability to the matrix, reduced the segregation of the alloying elements, made the solidification process of the interface more uniform, and effectively reduced the formation of interfacial pores and brittle compounds. The stress concentration regions formed by these pores and brittle compounds were reduced, and the bonding strength at the coating interface was improved.

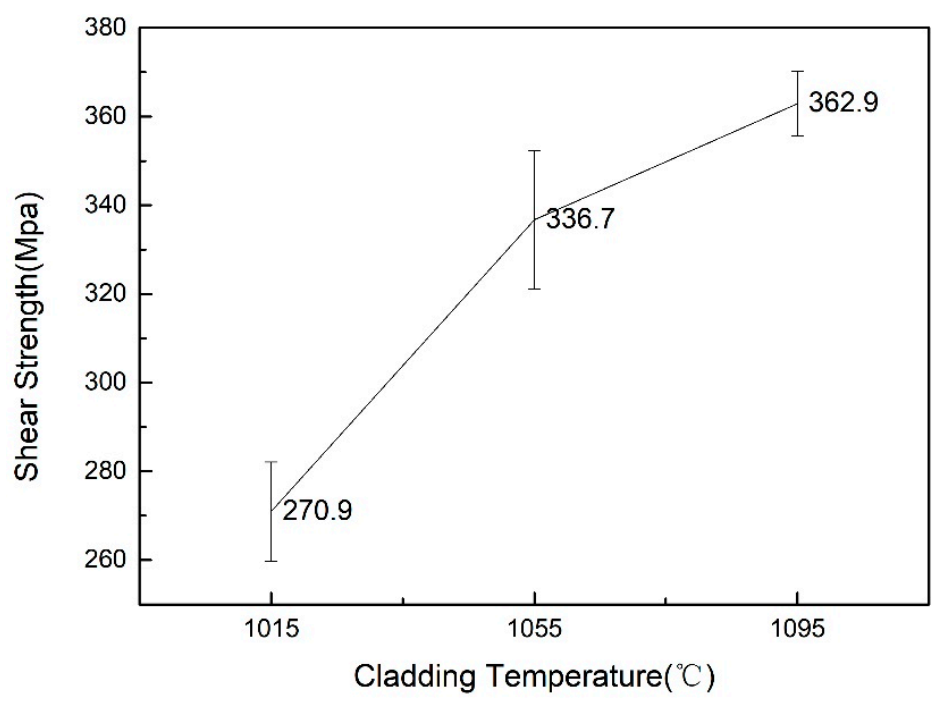

Figure 11. Shear strength of three coatings. 


\subsection{Wear Resistance of Composite Coating}

The wear resistance of the composite coating surface was not only related to the content of the hard-phase WC particles in the coating, but also to the bonding strength between the WC particles and the solder. As shown in Figure 12, under the same test conditions, the wear of the matrix was 2.7-4.6 times that of the three brazing temperature coatings. When the brazing temperature reached $1095^{\circ} \mathrm{C}$, the grinding loss of the sample was $3.3 \mathrm{mg}$, which was the lowest. The increase in brazing temperature was beneficial to the diffusion of the alloying elements into the WC particles, so the microstructure in the coating was more uniform. The degree of metallurgical bonding strength between the WC particles and the NiCrBSi solder increased, resulting in an increase in the resistance of the WC particles being peeled off and an increase in the wear resistance of the coating.

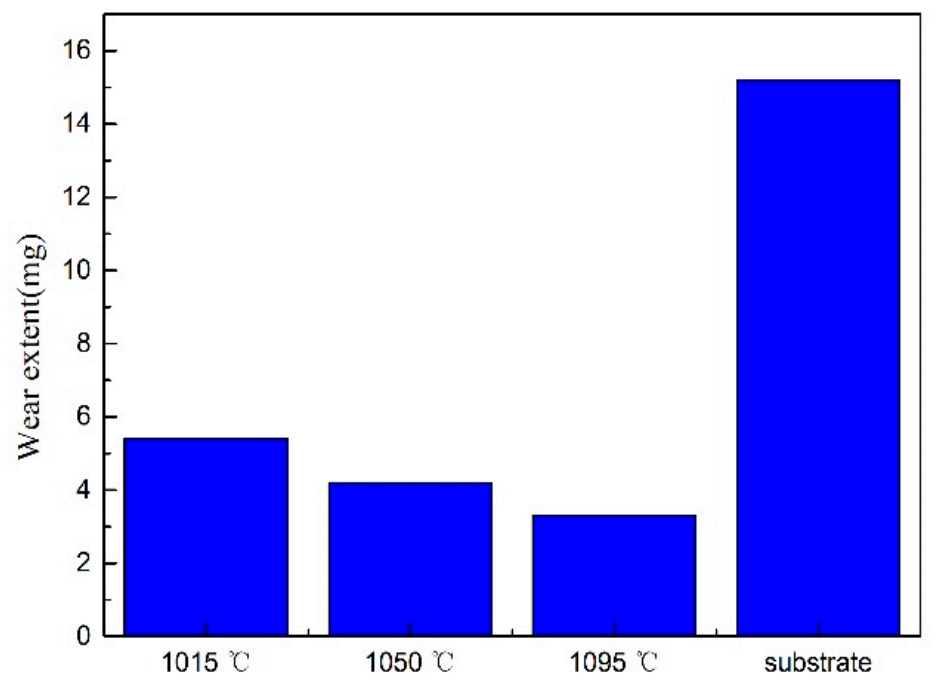

Figure 12. Wear loss of the coating and matrix surface.

\section{Conclusions}

- Three kinds of $\mathrm{WC}-10 \mathrm{Ni} / \mathrm{NiCrBSi}$ composite coatings were prepared on the surface of Q235 carbon steel at 1015,1055 , and $1095^{\circ} \mathrm{C}$ by vacuum brazing. Various reaction layers appeared at the bonding area of the coatings and the substrate. With the increase in brazing temperature, the reaction layer between the solder and the hard phase gradually decreased and disappeared at $1095^{\circ} \mathrm{C}$. Simultaneously, the size of gray-white massive phases with a large amount of $\mathrm{W}$ in the brazing layer decreased gradually.

- When the brazing temperature increased, the Fe content markedly increased in the reaction layer of the matrix and the solder. This indicated that the increase in brazing temperature was beneficial to metallurgical bonding between the coating and the matrix.

- Interface bonding strength and wear resistance were enhanced by the increase in brazing temperature. However, the microhardness of the composite coating section decreased. The interface bonding strength reached $362.9 \mathrm{MPa}$ and the wear loss reached a minimum at $1095^{\circ} \mathrm{C}$.

Author Contributions: Conceptualization, X.X.; Methodology, X.X. and H.D.; Validation, X.X., H.D., J.Z. and C.X.; Formal Analysis, X.X. and H.D.; Investigation, X.X., Y.W., H.D. and C.X.; Resources, J.Z.; Data Curation, X.X.; Writing-Original Draft Preparation, X.X. and H.D.; Writing-Review and Editing, J.Z. and C.X.; Supervision, J.Z. and C.X.; Project Administration, J.Z., X.X. and C.X.; Data Curation, X.X.; Resources, X.X. and J.Z.; Visualization, J.Z. and C.X.

Funding: This research received no external funding.

Conflicts of Interest: The authors declare no conflict of interest. 


\section{References}

1. Nahvi, S.M.; Jafari, M. Microstructural and mechanical properties of advanced HVOF-sprayed WC-based cermet coatings. Surf. Coat. Technol. 2016, 286, 95-102. [CrossRef]

2. Liu, L.; Xu, H.; Xiao, J.; Wei, X.; Zhang, G.; Zhang, C. Effect of heat treatment on structure and property evolutions of atmospheric plasma sprayed NiCrBSi coatings. Surf. Coat. Technol. 2017, 325, 548-554. [CrossRef]

3. Vashishtha, N.; Khatirkar, R.K.; Sapate, S.G. Tribological behaviour of HVOF sprayed WC-12Co, WC-10Co-4Cr and $\mathrm{Cr}_{3} \mathrm{C}_{2}-25 \mathrm{NiCr}$ coatings. Tribol. Int. 2017, 105, 55-68. [CrossRef]

4. Huang, S.; Sun, D.; Xu, D.; Wang, W.; Xu, H. Microstructures and Properties of NiCrBSi/WC Biomimetic Coatings Prepared by Plasma Spray Welding. J. Bionic Eng. 2015, 12, 592-603. [CrossRef]

5. Bartkowski, D.; Bartkowska, A. Wear resistance in the soil of Stellite-6/WC coatings produced using laser cladding method. Int. J. Refract. Met. Hard Mater. 2017, 64, 20-26. [CrossRef]

6. Alidokht, S.A.; Manimunda, P.; Vo, P.; Yue, S.; Chromik, R.R. Cold spray deposition of a Ni-WC composite coating and its dry sliding wear behavior. Surf. Coat. Technol. 2016, 308, 424-434. [CrossRef]

7. Xu, X.P.; Liu, Q.M.; Xia, C.Z.; Zou, J.S. Microstructure and properties of $\mathrm{Si}_{3} \mathrm{~N}_{4}$ ceramics and 304 stainless steel brazed joint with $\mathrm{Cu} / \mathrm{Ag}-\mathrm{Cu} / \mathrm{Ti}$ laminated filler metal. High Temp. Proc. 2018, 37, 597-602. [CrossRef]

8. Deschuyteneer, D.; Petit, F.; Gonon, M.; Cambier, F. Processing and characterization of laser clad NiCrBSi/WC composite coatings-Influence of microstructure on hardness and wear. Surf. Coat. Technol. 2015, 283, 162-171. [CrossRef]

9. Dariusz, B.; Grzegorz, K. Microstructure and wear resistance of Stellite-6/WC MMC coatings produced by laser cladding using Yb: YAG disk laser. Int. J. Refract. Met. Hard Mater. 2016, 58, 157-164.

10. Zou, J.S.; Jiang, Z.G.; Zhao, Q.Z.; Chen, Z. Brazing of $\mathrm{Si}_{3} \mathrm{~N}_{4}$ with amorphous $\mathrm{Ti}_{40} \mathrm{Zr}_{25} \mathrm{Ni}_{15} \mathrm{Cu}_{20}$ filler. Mater. Sci. Eng. A 2009, 507, 155-160. [CrossRef]

11. Xia, C.; Sun, W.; Zhou, Y.; Xu, X. Thermal fatigue damage and residual mechanical properties of $\mathrm{W}-\mathrm{Cu} / \mathrm{Ag}-\mathrm{Cu} /{ }_{1} \mathrm{Cr}_{1} 8 \mathrm{Ni}$, brazed joint. J. Alloy. Compd. 2018, 741, 155-160. [CrossRef]

12. Zou, J.; Liu, R.; Wang, L. Influence of Alloying Elements on Properties of Ti-Ni-Cu Brazing Alloys. Rare Met. Mater. Eng. 2010, 39, 1023-1026.

13. Bailey, J.; Worden, D.; Breton, E.; Wolf, J. Coating metallic substrate with powdered filler and molten metal. U.S. Patent 3743556, 3 July 1973.

14. Goldsmith, R. Method of preparing microporous tetrafluoroethylene resin sheets. U.S. Patent 3281511A, 25 October 1966.

15. Lu, S.; Dong, X.; Wu, Q.; Guo, Y.; Xu, X.; Zhu, Z. Preparation of NiCrBSi-WC wear-resistant brazing coatings. J. Met. 1999, 35, 83-85.

16. Tan, B.; Zhao, B.; Fan, J.; Gao, P. Study on the properties of WC "metal cloth" brazing wear layer by brazing temperature. Ordnance Mater. Sci. Eng. 2003, 254, 421-428.

17. Li, H.; Jia, Y.; Xuan, F. Preparation and performance of gradient WC reinforced NiCrBSi alloy coating based on flexible metallic cloth technique. Mech. Eng. Mater. 2018, 42, 59-64. [CrossRef]

18. Zhou, S.; Lei, J.; Dai, X.; Guo, J.; Gu, Z.; Pan, H. A comparative study of the structure and wear resistance of $\mathrm{NiCrBSi} / 50 \mathrm{wt}$ \% WC composite coatings by laser cladding and laser induction hybrid cladding. Int. J. Refract. Met. Hard Mater. 2016, 60, 17-27. [CrossRef]

19. Grunder, T.; Piquerez, A.; Bach, M.; Mille, P. Residual Stress in Brazing of Submicron $\mathrm{Al}_{2} \mathrm{O}_{3}$ to WC-Co. J. Mater. Eng. Perform. 2016, 25, 2914-2921. [CrossRef]

20. Pascal, D.T.; Şerban, V.A.; Marginean, G. Optimization of process parameters for the manufacturing of high temperature vacuum brazed WC-NiCrBSi Coatings. Solid State Phenom. 2016, 254, 164-169. [CrossRef]

21. Ortiz, A.; García, A.; Cadenas, M.; Fernández, M.R.; Cuetos, J.M. WC particles distribution model in the cross-section of laser cladded NiCrBSi + WC coatings, for different wt \% WC. Surf. Coat. Technol. 2017, 324, 298-306. [CrossRef]

22. Ramirez, C.; Ismail, A.I.; Gendarme, C.; Dehmas, M.; Aeby-Gautier, E.; Poulachon, G.; Rossi, F. Understanding the diffusion wear mechanisms of WC $-10 \%$ Co carbide tools during dry machining of titanium alloys. Wear 2017, 390, 61-70. [CrossRef]

(C) 2019 by the authors. Licensee MDPI, Basel, Switzerland. This article is an open access article distributed under the terms and conditions of the Creative Commons Attribution (CC BY) license (http:/ / creativecommons.org/licenses/by/4.0/). 